\title{
Cytogenetic effects of long-term radiation on higher aquatic plants within the Chernobyl accident Exclusion Zone
}

\author{
N.L. Shevtsova and D.I. Gudkov \\ Department of Radioecology, Institute of Hydrobiology of the National Academy of Sciences \\ of Ukraine, Geroyev Stalingrada Ave. 12, UA-04210 Kiev, Ukraine
}

\begin{abstract}
The rate of chromosome aberrations has been studied in higher aquatic plants: common reed, sagittaria, flowering rush and manna. The main water bodies were Glubokoye and Dalekoye-1 Lakes (leftbank flood lands of the Pripyat River), Azbuchin Lake and Yanovsky Crawl (right-bank flood lands of the Pripyat River), Cooling Pond of the Chernobyl NPP as well as Pripyat and Uzh Rivers. In decreasing sequence due to the absorbed dose rate for hydrobionts the first were water bodies of the left-bank flood lands of the Pripyat River, the second ones from right-bank flood lands. The highest chromosome aberrations rate in root meristems was registered in plants from lakes within the left-bank flood lands of the Pripyat River, the lowest one - in plants from the Pripyat and Uzh Rivers. The chromosome aberration rate in closed and slow-running water bodies within the right-bank flood lands of the Pripyat River was in 3-4 times higher than spontaneous mutagenesis level. It seems that spectrum of the main types of chromosome damages in plants of right-bank flood lands determines by chemical mutagens. The type of chromosome damages distribution in plants of the left-bank flood lands points to practically equivalent effects of radiation and chemical factors.
\end{abstract}

\section{INTRODUCTION}

The problem of study of biological effects of long-term low-dose environmental radiation impact on non-human biota and search of the most typical biological changes due to this impact occupied is one of the key places in modern radioecology. The contaminated territories of the Chernobyl accident Exclusion Zone give an opportunity to investigate radiation effects of chronic exposure on living organisms by the different types of irradiation. Also one of the background factors of these territories is a continuous low-dose irradiation as a consequence of the Chernobyl accident. The genetic test-systems are the most reliable and sensitive parameters of the damage processes for biota within radioactive contaminated areas.

\section{MATERIALS AND METHODS}

Our research was carried out during 2004-2006 in water bodies within the 30-km Exclusion Zone of the Chernobyl NPP. Sampling of higher aquatic plants for cytogenetic analysis, and measurement of radionuclide content were carried out within the littoral zone of Azbuchin Lake, Yanovsky (Pripyatsky) Crawl, cooling pond of the Chernobyl NPP, the lakes of the left-bank dammed flood plain of the Pripyat River - Glubokoye Lake and Dalekoye-1 Lake as well as Uzh River (near by Cherevach village) and Pripyat River (near by Chernobyl town). For comparison the sampling station with background radiation - Goloseevo Lake, located within the Kiev City area, was used. External dose rate due to gamma-irradiation was measured by the field radiometers DKS-01 and SRP-68-03. Internal absorbed dose rate was estimated from radionuclides ${ }^{90} \mathrm{Sr},{ }^{137} \mathrm{Cs},{ }^{238} \mathrm{Pu},{ }^{239+240} \mathrm{Pu}$ and ${ }^{241} \mathrm{Am}$ with use of dose conversion coefficients [1].

The rate of chromosome aberrations was studied in the apical root meristems of the four species of higher aquatic plants: common reed (Phragmites australis), arrowhead (Sagittaria sagittifolia), 
flowering rush (Butomus umbellatus) and manna (Glyceria maxima). The chromosome aberration rate was analysed by the modified for macrophytes anaphase method [2].

\section{RESULTS AND CONCLUSIONS}

The values of the absorbed dose for higher aquatic plants from water bodies of the Chernobyl Exclusion Zone were found to be in the range from 0,0018 to $0,16 \mathrm{~Gy} \mathrm{year}^{-1}$. The highest value was found for hydrobionts from lakes within embankment territory on the left-bank flood plain of Pripyat River, the lowest - for specimens from the running water objects - Uzh River and Pripyat River (Table 1).

Table 1. Diapasons for the absorbed dose rate for higher aquatic plants of littoral zone of water bodies within the sampling sites, Gy year ${ }^{-1}$.

\begin{tabular}{|l|c|c|c|}
\hline & External $\gamma$-dose & $\begin{array}{c}\text { Internal dose from } \\
\text { incorporated } \\
\text { radionuclides }\end{array}$ & Total dose \\
\hline Glubokoe Lake & $4.0 \mathrm{E}-02-4.2 \mathrm{E}-02$ & $3.9 \mathrm{E}-02-1.2 \mathrm{E}-01$ & $7.9 \mathrm{E}-02-1.6 \mathrm{E}-01$ \\
\hline Dalekoe-1 Lake & $2.5 \mathrm{E}-02-2.9 \mathrm{E}-02$ & $8.5 \mathrm{E}-03-4.2 \mathrm{E}-02$ & $3.4 \mathrm{E}-02-7.1 \mathrm{E}-02$ \\
\hline Azbuchin Lake & $3.8 \mathrm{E}-03-4.2 \mathrm{E}-03$ & $1.3 \mathrm{E}-02-6.8 \mathrm{E}-02$ & $1.7 \mathrm{E}-02-7.2 \mathrm{E}-02$ \\
\hline Yanovsky Crawl & $1.2 \mathrm{E}-02-1.3 \mathrm{E}-02$ & $4.2 \mathrm{E}-03-4.4 \mathrm{E}-02$ & $1.6 \mathrm{E}-02-5.7 \mathrm{E}-02$ \\
\hline Cooling pond & $7.1 \mathrm{E}-03-8.2 \mathrm{E}-03$ & $6.0 \mathrm{E}-03-2.3 \mathrm{E}-02$ & $1.3 \mathrm{E}-02-3.1 \mathrm{E}-02$ \\
\hline Pripyat River & $2.3 \mathrm{E}-03-3.6 \mathrm{E}-03$ & $1.40 \mathrm{E}-04-5.4 \mathrm{E}-04$ & $2.4 \mathrm{E}-03-4.1 \mathrm{E}-03$ \\
\hline Uzh River & $1.7 \mathrm{E}-03-2.9 \mathrm{E}-03$ & $1.1 \mathrm{E}-04-3.6 \mathrm{E}-04$ & $1.8 \mathrm{E}-03-3.3 \mathrm{E}-03$ \\
\hline Goloseevo Lake & $2.1 \mathrm{E}-04-2.6 \mathrm{E}-04$ & $0.5 \mathrm{E}-04-1.3 \mathrm{E}-04$ & $2.6 \mathrm{E}-04-3.9 \mathrm{E}-04$ \\
\hline
\end{tabular}

According to the classification of G.G. Polikarpov [3], the studied littoral sites of Uzh and Pripyat rivers belongs to the radiation safety zone; the sampling stations of Azbuchin Lake, Yanovsky Crawl, the Chernobyl NPP cooling pond and Dalekoye-1 Lake are zones of physiological and ecological disguise, where the radiobiological effects are difficult to detect due to the influence of other ecological factors. Glubokoye Lake approaches to the ecosystem of effect zone where reduction in aquatic organism numbers and loss of radiosensitive species can be observed.

Common reed is the most widespread and mass-grow species of the helophytes (aerial-aquatic plants) within the Chernobyl Exclusion Zone and background radioactivity water body. We have analysed 8987 root cells from 87 plants and measured 721 aberration cells and 781 aberrations.

The spontaneous rate of aberrant cells for hydrobionts does not increase 2\% [4]. We found $4.5 \%$ aberrant cells in common reed of the Pripyat River, and $2.2 \%$ in the Uzh River. More high level were registered in the cooling ponds of the Chernobyl NPP and Yanovsky Crawl $-6.1 \%$ and $7.5 \%$ respectively. Maximum rate of chromosome aberration was registered in plants from Azbuchin, Glubokoe and Dalekoe-1 lakes $-9.0 \%, 10.8 \%$ and $17.8 \%$ respectively. In comparison, the data received for reed from Goloseevo Lake amount to $1.0 \%$. The rate of chromosome aberration in reed from closed water bodies within the left-banked flood plain of the Pripyat River was in 5-8 times higher than spontaneous mutagenesis level.

As shown in Fig. 1. the single fragments were the frequently occurring aberration in meristem cells of reed $-57.1 \%$ of all aberrations. Rate of single bridges were $40.7 \%$, plural aberration, including different variation of fragments and/or bridges (pair bridges or fragments, bridge and fragment, bridge and two fragments, three fragments), were $2.3 \%$.

It seems that spectrum of the main types of chromosome damages in plants of water bodies of the right-bank flood plain of Pripyat River determines by the chemical mutagens (up to 69\% of single fragments). The type of chromosome damages distribution in plants from lakes within embankment territory on the left-bank flood plain of the Pripyat River points to practically equivalent effects of radiation and chemical factors $-44-49 \%$ of bridges, $43-50 \%$ of fragments and $6-8 \%$ of plural aberrations. 


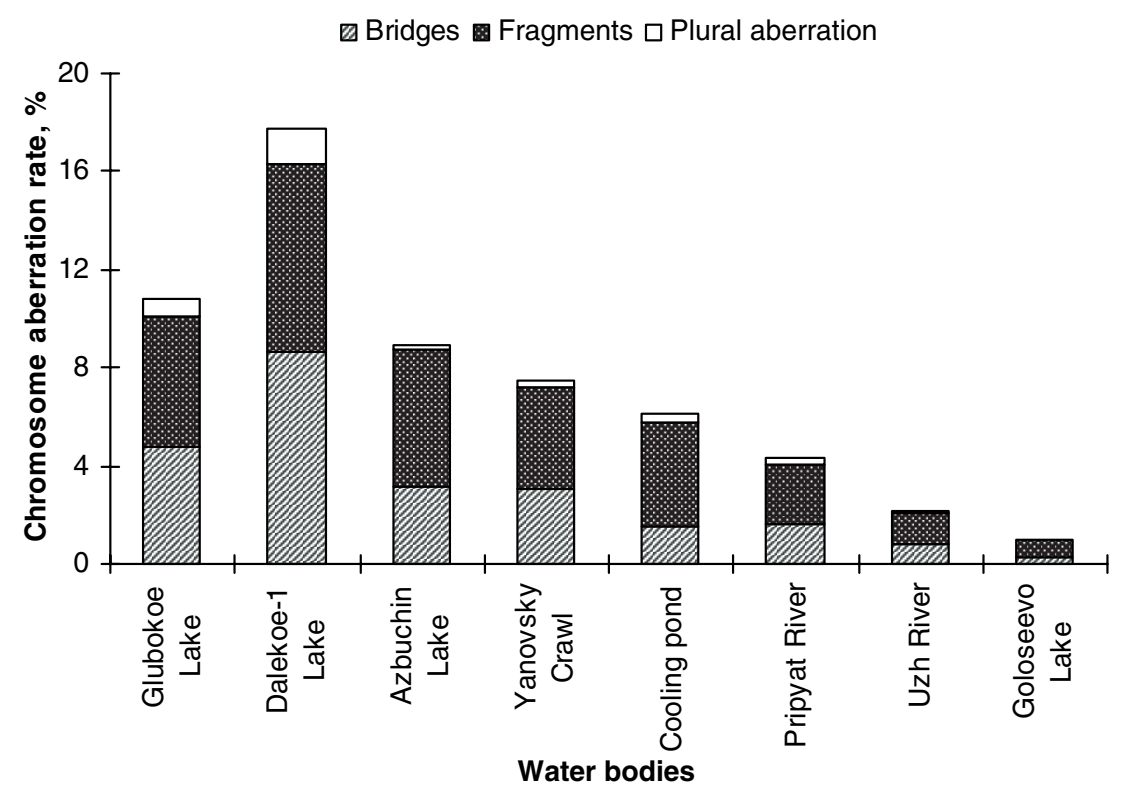

Figure 1. Spectrum of the main chromosome aberration in cells of the common reed from water bodies within the Chernobyl accident Exclusion Zone.

The arrowhead was sampled in Glubokoe Lake and the Pripyat River (near by Chernobyl town) only. The rate of chromosome aberrations in arrowhead's cells did not exceed $2.5 \%$ in the Pripyat River and was about $6.5 \%$ in plants from Glubokoe Lake (Fig. 3). Flowering rush and manna were sampled in Azbuchin Lake and Dalekoe-1 Lake. The rate of aberrant cells in these plants reached to 5.9-6.2\% in Azbuchin Lake and to 9.5-11.3\% in Dalekoe-1 Lake.

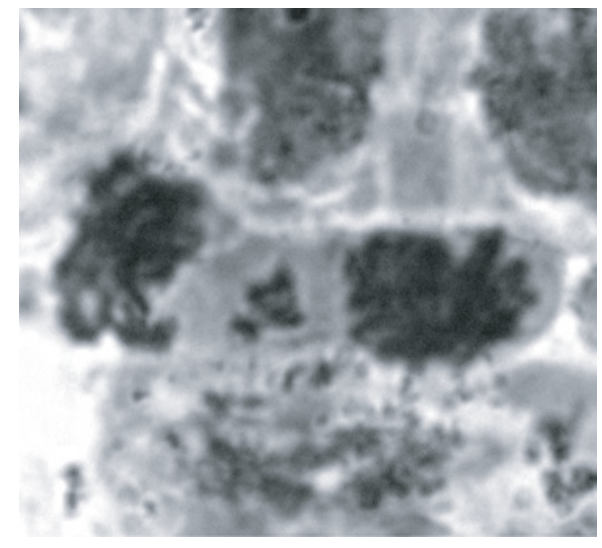

a)

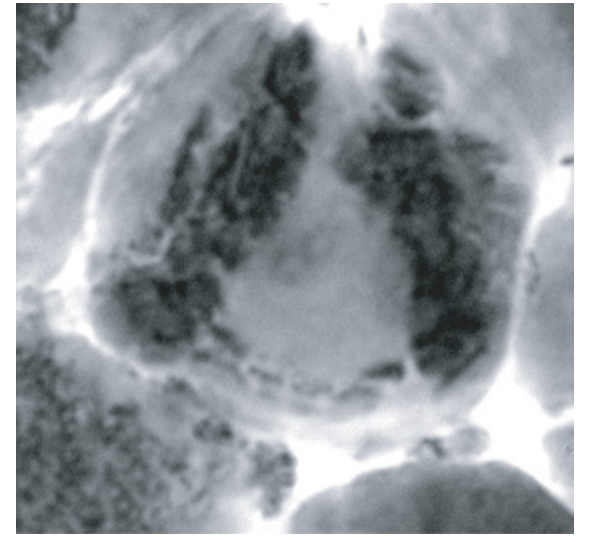

b)

Figure 2. Chromosome aberrations in the apical root meristem cells of arrowhead (Sagittaria sagittifolia, from the Glubokoe Lake: a) plural fragments, b) double bridge. 
The positive correlation between absorbed dose and rate of aberrant cells of apical root meristem of common reed was found (Fig. 3). According to our data this dependence more corresponds to a power-mode function.

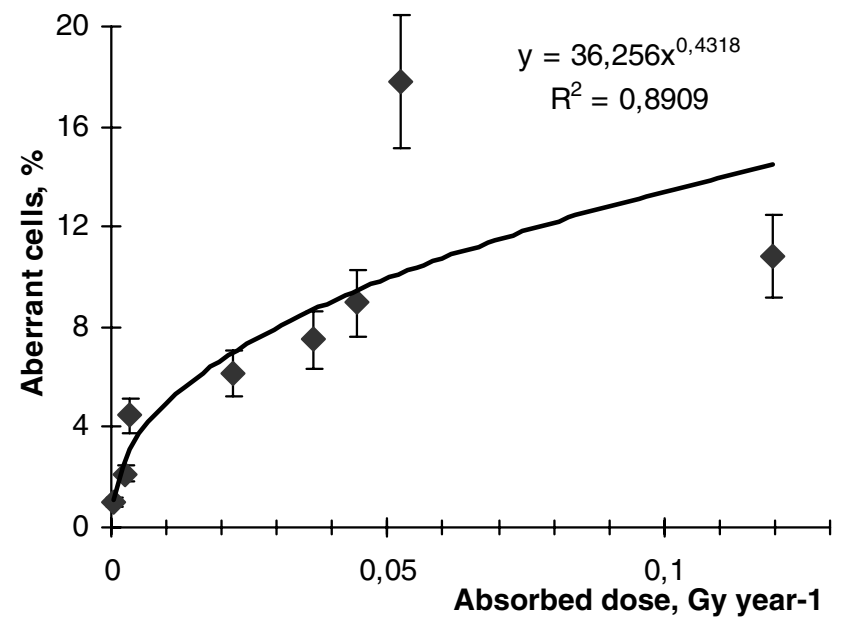

Figure 3. The dependence of chromosome aberration rate from absorbed dose rate in cells of common reed from water bodies within the Chernobyl accident Exclusion Zone.

The studies of the different species of plants within the exclusion zone have revealed a numerous morphological anomalies as repeated organs, gigantism or dwarf, underdevelopment or sterility of reproductive organs, excessive branching, growth inhibition of the secondary points of growth etc. All of this variety of plant anomalies of development is testify that the vegetation within the exclusion zone has undergone to strong damage of the genotype, which consequence is the long genetic instability and thus increased variability of many species.

An increasing importance of the genetic damages induced by a long-term irradiation is expected. These remote consequences are delayed manifestation of changes in germ cells, where the initial molecular damages have a latent period, without any evident effect, but can be transferred through many generations of cells to trigger genome instability in future. The long-term impact of low dose irradiation in aquatic ecosystems, especially in closed water bodies within the Chernobyl Exclusion Zone, is shown by the increased level of chromosome aberrations and concerned with it a reproductive death of cells.

\section{Acknowledgments}

The authors wish to thank the personnel of Radioanalytical Laboratory of the Chernobyl Radioecological Centre for the radionuclide measuring procedure.

\section{References}

[1] Brown, J., Strand, P., Hosseini, A. and Borretzen, P. (Eds) Handbook for assessment of the exposure of biota to ionising radiation from radionuclides in the environment. A project within the EC 5th Framework Programme, Contract \# FIGE-CT-2000-00102, Framework for Assessment of Environmental Impact, 2003, 395 p.

[2] Polikarpov, G.G. Radiat. Protect. Dosim., 75, (1998), pp. 181-185.

[3] Shevtsova, N.L., Gudkov, D.I., Stoyko, U.A. and Syvak, E.V. Scientific Acta of the Ternopil State Teacher's Training University, 3, (2005), pp. 478-479 (Rus).

[4] Tsytsugina, V.G., Radiat. Protect. Dosim., 75(1), (1998), pp. 171-173. 